\title{
A Folk Medicine: Passiflora incarnata L. Phytochemical Profile with Antioxidant Potency
}

\author{
(1) Helan Soundra Rani MICHAEL ${ }^{1 *}$, (1) Nazneen Bobby MOHAMMED2² (1) Subramaniam PONNUSAMY33, (1) Wesely EDWARD GNANARAJ3 \\ 1Sri Ramakrishna College of Science, Department of Biotechnology, Coimbatore, India \\ 2Vignan's Foundation for Science Technology and Research, Department of Biotechnology, Vadlamudi, Guntur Dist. AP., India \\ ${ }_{3}^{3}$ Arignar Anna Government Arts College, P.G and Research Centre in Botany, Namakkal, India
}

\begin{abstract}
Objectives: Passiflora incarnata L., commonly called folk medicine declaredly used for an enormous range of therapeutic purposes, one such is antioxidant potency. The study prioritized to determine the phytochemical analysis of total phenolics, flavonoids, alkaloids, and tannins contents as well as the antioxidant properties through 1,1-diphenyl-2-picrylhydrazyl (DPPH) quenching assay, 2,2-azino-bis-(3-ethylbenzothiazoline-6-sulfonic acid) (ABTS) cation decolorization test, superoxide, and hydrogen peroxide radical scavenging assays of ethanol extract of $P$. incarnata leaves.

Materials and Methods: The organoleptic characteristics such as color, odor, appearance, taste, and other characters such as drying range and fiber contents were analyzed as preliminary data. Analytical parameters like total phenolic content, total tannins, total alkaloid content, and total flavonoid with multiple antiradical scavenging activity (DPPH, ABTS, superoxide and $\mathrm{H}_{2} \mathrm{O}_{2}$ scavenging assays) with $I \mathrm{C}_{50}$ ( $\mu \mathrm{g} / \mathrm{mL}$ ) in terms of inhibition percentage with various concentrations of the ethanolic extract studied.

Results: $P$. incarnata possessed a high radical scavenging activity with a phenolic content of $2.48 \mathrm{mg}$ gallic acid equivalent/g of extract in leaves, whereas the total flavonoid content was 2.1, respectively.

Conclusion: High antioxidant activity was noticed in $P$. incarnata extract, in which might be of higher levels of flavonoids and phenols. Findings in the studies revealed that $P$. incarnata is a veritable source for antioxidant drug bioprospecting in scientific research and pharmaceutical industries.

Key words: Passiflora incarnata, phytochemical profile, antioxidant activity, DPPH, ABTS, radical scavenging activity
\end{abstract}

\section{INTRODUCTION}

Singlet oxygen is formed in the biological system in aerobic organisms for normal cell functions, if exceed, the reactive oxygen species (ROS) level in the living system causes oxidative stress and leads to oxidative damage. These ROS intermediate threaten various biomolecules including proteins, enzymes, lipids, and DNA ${ }^{1,2}$ and also cause physiological errors like blocks in arteries, strokes, cancer, and nervous disorders, which highly possess to increase in the study of compounds that protect against ROS and can prevent diseases. ${ }^{3,4}$ As a result, high priority to be enlightened to the purpose of antioxidants, particularly organic-based to protect from damage due to free radicals. ${ }^{5}$ Antioxidants, compounds that can delay or prevent the oxidation of biomolecules by blocking engagement of oxidative progress that can avoid or restore the damage by ROS. ${ }^{6}$ However, synthetic antioxidants, e.g. propylgallate, butylated hydroxyanisole, butylated hydroxytoluene, and tertiary butylhydroquinone, are recognized as good oxidative costs, yet, they have limitations because of their carcinogenic effects on the lungs and liver parts. ${ }^{7}$ So, recently, several excessive efforts have been outworthed to safeguard potent organic tagged antioxidants from ethnomedicinal sources.

Natural antioxidants, principally from plants with that sort of phenolic compounds, vitamin C, and carotenoids. Ethnomedicinal-based compounds have multiplex biological effects, including antioxidant potentials with its phytoconstituents including phenolics and flavonoids. ${ }^{8}$ Nutritional components from plants are the dynamic cause of various classes of polyphenolic components and some flavonoids. ${ }^{9}$ Some phytomedicines are traditional, among them, Passiflora sp. has been reported as folk medicine. Passiflora genus, Passifloraceae, includes about 520 
species, ${ }^{10}$ which are spotted mostly in tropical and subtropical regions of the world. Passiflora incarnata L., P. alata Curtis, $P$. mucrinata Lam., and $P$. edulis Sims reveal their potential biological activity by its various phytometabolites such as phenolic substances, alkaloids, and flavonoid contents, and it is known for its sedative properties as well as in the food and pharmaceutical industry. ${ }^{11}$ In spite of extensive research on plant products, the efficacy of plant sources as novel drugs is still meagerly documented. Only a least fraction has been studied phytochemically and therefore, the fractions recommended for biological or pharmacological screening are even smaller. Hence, an attempt made to evaluate the leaves of $P$. incarnata to reveal its antioxidant potential.

\section{MATERIALS AND METHODS}

\section{Collection of plant material}

P. incarnata was collected from Keezanatham, Ariyalur (Dt.), Tamil Nadu, India (Figure 1). Identification of plant material was validated by Prof. Jegadeesan Head, Department of Environmental and Herbal Sciences, Tamil University, Thanjavur). Furthermore, it was confirmed with Herbarium sheets available in the Rabinat Herbarium, St. Joseph's College, Thiruchirappalli, Tamil Nadu, India. The specimen was kept in the Herbarium of Arignar Anna Government Arts College, Department of Botany (AAGAC/BOT-07). The fresh and fully-grown plant leaves were selected. The collected plant leaves were cleaned to remove mud and other adhering weed plants. Fresh leave samples were desiccated at the room temperature and then shade-dried for 2-3 days and powdered mechanically, sieved using 80 meshes, and refrigerated. ${ }^{12}$

\section{Preliminary phytochemical studies}

\section{Organoleptic characters}

Color, odor, appearance, taste and other characters like drying range and fiber contents of the grounded sample were determined. The sample ( $2 \mathrm{~g}$ ) was allowed to dry in a tarred dish and with the temperature of $100-105^{\circ} \mathrm{C}$, it was then allowed to cool and weigh again.

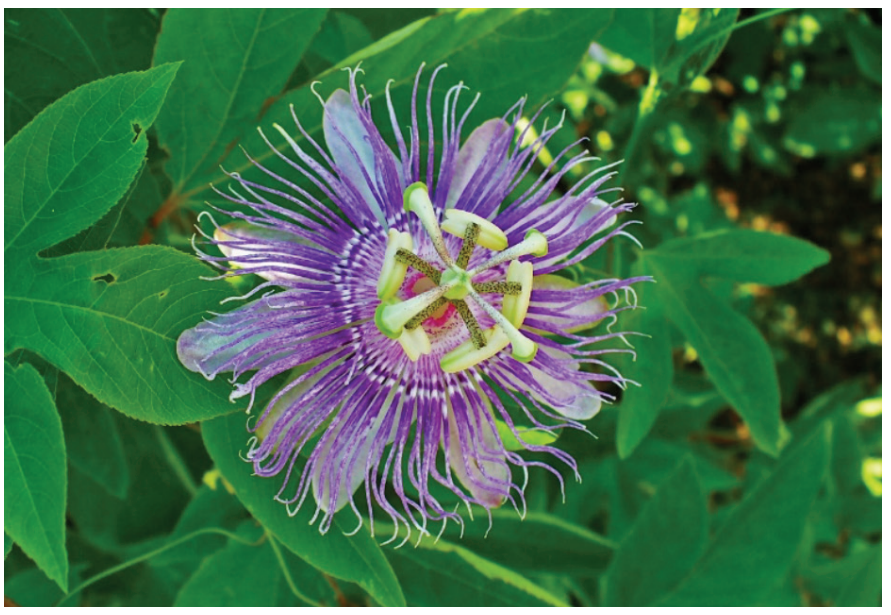

Figure 1. Passiflora incarnata L. Photo courtesy: P. Subramaniam

\section{Analytical parameters}

Total ash

$5 \mathrm{~g}$ sample was exposed in silica crucible, which is ignited prior, allowed to cool and weighed. It was allowed to incinerate with slow progression of heat, up to $450^{\circ} \mathrm{C}$, allow to cool and weigh again. The percentage of total ash was calculated using the reference range and repeated again until, a constant weight was noted.

\section{Acid-insoluble ash}

Total ash was allowed to boil with $25 \mathrm{~mL}$ (10\%) of diluted $\mathrm{HCl}$ for about 5 min and filter it, then ignite it to obtain acid insoluble ash.

\section{Water-soluble ash}

To check the water-soluble ash, a portion of the total ash was allowed to boil in $25 \mathrm{~mL}$ of $\mathrm{H}_{2} \mathrm{O}$ for $5 \mathrm{~min}$ and wash the filtered debris was with hot water. The water-soluble ash was calculated.

Water soluble ash= Total ash value - Water-insoluble ash

\section{Sulfated ash}

A portion of the sample was ignited with $1 \mathrm{~mL}$ of $\mathrm{H}_{2} \mathrm{SO}_{4}$. It was then cooled, and percentage of sulfated ash was calculated.

\section{Extractive values}

The dried sample $(5 \mathrm{~g})$ was impregnated with moderately hot petroleum ether overnight. The extract was concentrated and weighed. ${ }^{13}$

\section{Preparation of the extract}

The shade-dried leaves were pulverized to get a coarse powder..$^{14}$ The ground plant material $(1 \mathrm{~kg})$ was soaked separately in ethanol for $48 \mathrm{hrs}$. The aqueous extraction was gained through filtration method. The extract was then subjected to dryness in an evaporator under controlled pressure and temperature $\left(40-50^{\circ} \mathrm{C}\right)$.

\section{Chemicals}

2,2-Azinobis-3-ethylbenzothiazoline-6-sulfonic acid (ABTS), 1, Folin-Ciocalteu's phenol reagent, 1,1-diphenyl-2-picrylhydrazyl (DPPH), ascorbic acid, Folin-Danis reagent, bromocresol green solution (BCG), dimethyl sulfoxide (DMSO), potassium persulfate, methanol, and sodium carbonate were purchased from Sigma Chemical Co. (St. Louis, MO, USA).

\section{Estimation of total phenolic content}

The extract was allowed to incubate for 5 minutes prior with $0.3 \mathrm{~mL}$ of Folin-Ciocalteu's reagent. $\mathrm{Na}_{2} \mathrm{CO}_{3}(7 \%, 10 \mathrm{~mL})$ solution was mixed and incubated for $2 \mathrm{~h}$ absorbance was measured at $740 \mathrm{~nm}$. Quantification was conducted using a gallic acid (GA) as the standard. The results are expressed as milligrams per gram dry weight. ${ }^{15}$

\section{Estimation of tannins}

Folin-Danis reagent $(0.5 \mathrm{~mL})$ was added to each tube containing different concentrations of the sample and kept for 3 minutes. Further, $2 \mathrm{~mL}$ of $20 \% \mathrm{Na}_{2} \mathrm{CO}_{3}$ solution was added and gently vortex. The test tubes were kept in boiling 
for $1 \mathrm{~min}$ and cooled down. The absorbance was measured at $650 \mathrm{~nm}^{16}$

\section{Estimation of total alkaloid content}

A portion of extract residue was dissolved in $2 \mathrm{~N} \mathrm{HCL}$ for 20 minutes and then filtered. $1 \mathrm{~mL}$ solution was transferred to a separatory funnel and washed with $10 \mathrm{~mL}$ chloroform (thrice). The hydrogen ion range of the solution was adjusted to neutral. BCG with phosphate buffer $(5 \mathrm{~mL})$ was mixed with the mixture. The extract with chloroform was mixed by continuous shaking, then the extract was collected in a $10 \mathrm{~mL}$ flask, and diluted again with chloroform. The precipitate was collected and dried at $105^{\circ} \mathrm{C}$ to constant weight and weighed.

\section{Estimation of total flavonoid content}

The sample $(10 \mathrm{~g})$ was impregnated with $60 \mathrm{~mL}$ methanol and allowed to stand overnight. The residue was filtered and washed twice with $20 \mathrm{~mL}$ methanol. Filtrate was washed and concentrated to $10 \mathrm{~mL}$. The concentrated solution was added drop wise continuously shaken into $100 \mathrm{~mL}$ ether. Mix vigorously for 10 minutes and allowed to stand for 10 minutes to settle. Filtrate was evaporated to dry and calculated.

\section{In vitro antioxidant activity}

\section{$D P P H$ radical scavenging activity}

The plant extract at different concentrations was diluted with DMSO to get a sample solution. The sample $(5 \mu \mathrm{L})$ was seeded in a 96-well plate followed by $195 \mu \mathrm{L}$ DPPH working solution to each well. After 20 min reaction, the absorbance was measured at $515 \mathrm{~nm}$. The free radical activity of the extract was determined by comparing its absorbance with blank. ${ }^{17}$ The scavenging ability by DPPH radical was expressed as a percentage of inhibition and was calculated.

DPPH scavenging activity $(\%)=\left(A_{0}-A_{1}\right) / A_{0} \times 100$

where $A_{0}$ : Absorbance of the control, and $A_{1}$ : Absorbance of the sample.

\section{ABTS radical scavenging activity}

ABTS radical was formed with the addition of $5 \mathrm{~mL}$ of ABTS stock solution and $2.45 \mathrm{mM} \mathrm{K}_{2} \mathrm{~S}_{2} \mathrm{O}_{8}$ solutions respectively, and stored in the dark at room temperature for 16 hs. Before use, this solution was diluted and the absorbance was notably at $0.700 \pm 0.020$ at $734 \mathrm{~nm}$ and maintained at $30^{\circ} \mathrm{C}$. The extract at various concentrations was diluted with DMSO, which counts for the sample solution. $5 \mu \mathrm{L}$ of sample solution was mixed with $195 \mu \mathrm{L}$ ABTS + solution, and incubated at room temperature for $6 \mathrm{~min}$ and the absorbance was recorded at $734 \mathrm{~nm} .{ }^{18}$ ABTS scavenging activity was expressed as $I_{50}(\mu \mathrm{g} / \mathrm{mL})$ and the inhibition percentage was calculated.

ABTS scavenging activity $=\left(A_{0}-A_{1}\right) / A_{0} \times 100$

\section{Hydrogen peroxide scavenging activity}

Hydrogen peroxide was prepared with phosphate buffer $(\mathrm{pH}$ 7.4). Different concentrations of sample $(200 \mu \mathrm{L})$ were mixed with $0.6 \mathrm{~mL}$ of $\mathrm{H}_{2} \mathrm{O}_{2}$ solution. A test tube containing $200 \mu \mathrm{L}$ of phosphate buffer was processed as discussed above act as a control. Different concentrations of ascorbic acid were used as the reference compound. Absorbance of $\mathrm{H}_{2} \mathrm{O}_{2}$ was determined against a blank. ${ }^{19}$

\section{Superoxide scavenging activity}

The sample $(200 \mu \mathrm{L})$ of different concentrations was taken in test tubes. Superoxide radicals were produced by equal addition of $1 \mathrm{~mL}$ of Tris-HCl buffer $(16 \mathrm{mM}, \mathrm{pH}-8)$, nitro blue tetrazolium $(50 \mu \mathrm{M})$, nicotinamide adenine dinucleotide $(78 \mu \mathrm{M})$ solution and phenazine methosulphate $(10 \mu \mathrm{M})$ respectively. The mixtures were then incubated at $25^{\circ} \mathrm{C}$ for $5 \mathrm{~min}$ and measured the absorbance $(560 \mathrm{~nm}) .^{20}$

\section{Statistical analysis}

The experimental results were expressed as \pm standard deviation. Data were analyzed with ANOVA and determined by Duncan's Multiple Range test using Graph Pad Prism software version 5.0 (San Diego, USA).

\section{RESULTS}

The organoleptic characteristics and analytical parameters of the leaf powder of $P$. incarnata were studied (Table 1). The ratio of active chemical components in unpolished drugs are mainly based on air-dried. Therefore, ranging the dryness of plant materials should be evaluated, particularly for the materials that imbibe moist easily. The residue remaining after incineration of the plant material is the ash content, which simply represents some inorganic salts and occurs naturally in unprocessed crude drug materials.

\section{Phytochemical analysis}

The total phenolic content in examined leaf extract was $2.8 \mathrm{mg}$ GA equivalent/g and showed flavonoids $(2.1 \mathrm{mg} / \mathrm{g}$ ) but in merger range compared with phenolic contents (Table 2). Total tannin content of $P$. incarnata leaf extracts show $1.9 \mathrm{mg} / \mathrm{g}$ and alkaloids $0.031 \mathrm{mg} / \mathrm{g}$. The high antioxidant activity was observed in $P$. incarnata extract, which evidenced the high level of flavonoids and phenolic presence in the plant (Table 3).

\section{Table 1. Organoleptic characteristics of Passiflora incarnata}

leaves

\begin{tabular}{ll} 
Appearance & Coarse powder \\
\hline Color & Green \\
\hline Odor & No characteristic \\
\hline Taste & Slightly bitter \\
\hline \% Loss on drying & 7.12 \\
\hline Crude fiber & 9.4 \\
\hline
\end{tabular}

\section{Table 2. Analytical parameters}

\begin{tabular}{ll} 
Parameters & Value in $\mathbf{w} / \mathbf{w}$ \\
\hline Total ash & 9.23 \\
\hline Acid-insoluble ash & 10.3 \\
\hline Water-soluble ash & 6.50 \\
\hline Sulfated ash & 18.20 \\
\hline
\end{tabular}




\section{In vitro antioxidant activity}

Inhibition\% of DPPH by the extract at different concentrations $(1,2,4$, and $8 \mu \mathrm{g} / \mathrm{mL})$ was observed to be $17.43 \pm 0.31,30.12 \pm$ $0.29,51.69 \pm 0.43$, and $80.91 \pm 0.37$, respectively, whereas the percentage inhibition of ascorbic acid was found to be $22.13 \pm$ $0.28,39.87 \pm 0.33,57.28 \pm 0.25$, and $82.55 \pm 0.41 . I_{50}$ values for DPPH scavenging activity of the leaf extract of $P$. incarnata and ascorbic acid were $4.30 \mu \mathrm{g} / \mathrm{mL}$ and $3.69 \mu \mathrm{g} / \mathrm{mL}$, respectively (Figure 2, Table 4). The extract exhibited good ABTS radical scavenging activity and inhibition\% (with various concentration $1,2,4,8 \mu \mathrm{g} / \mathrm{mL}$ ) was found to be $14.65 \pm 0.17,32.16 \pm 0.24$, $49.87 \pm 0.30$, and $75.23 \pm 0.33$, respectively, which were comparable to that of ascorbic acid $19.32 \pm 0.21,40.28 \pm 0.27$, $60.71 \pm 0.31$, and $77.56 \pm 0.29$. IC $C_{50}$ values for scavenging ability on ABTS radical of the extract of $P$. incarnata, while $\mathrm{IC}_{50}$ values by ascorbic acid were $4.60 \mu \mathrm{g} / \mathrm{mL}$ and $3.82 \mu \mathrm{g} / \mathrm{mL}$, respectively (Figure 3, Table 5).

$P$. incarnata leaf extracts exhibited a strong scavenging effect on hydrogen peroxide were recorded as $12.43 \pm 0.87,28.57 \pm$ $0.67,41.32 \pm 0.72$, and $62.84 \pm 0.60$ respectively (Figure 4 , Table 6). Contrast, $18.21 \pm 0.52,39.52 \pm 0.41,50.43 \pm 0.39$, and 66.16 \pm 0.47 was noted in standard ascorbic acid. $I C_{50}$ values for $\mathrm{H}_{2} \mathrm{O}_{2}$ scavenging activity for ethanol extract of leaves of $P$. incarnata and ascorbic acid were 5.79 and $4.80 \mu \mathrm{g} / \mathrm{mL}$. Superoxide radical scavenged by the plant extract at different concentrations were observed as $20.15 \pm 0.45,29.42 \pm 0.38,48.88 \pm 0.35$, and 74.37 \pm 0.51 for the leaf extract, while the reference was found to be $25.53 \pm 0.29,37.19 \pm 0.33,55.26 \pm 0.34$, and $77.55 \pm 0.39$ respectively. $\mathrm{IC}_{50}$ value of ascorbic acid was $3.90 \mu \mathrm{g} / \mathrm{mL}$, while the leaf extract's was $4.63 \mu \mathrm{g} / \mathrm{mL}$ (Figure 5, Table 7). Values are

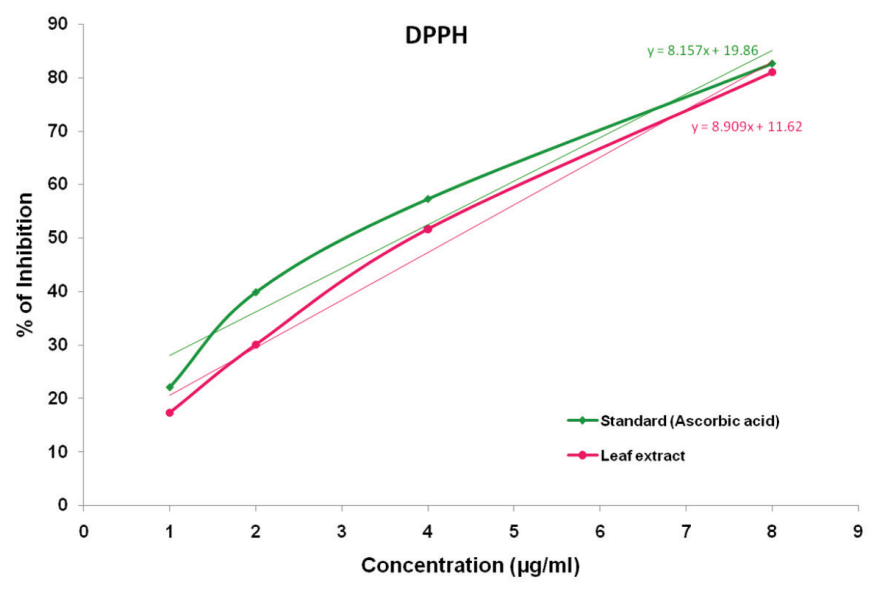

Figure 2. DPPH radical scavenging activity

Table 3. Polyphenol content of the ethanolic leaf extract of Passiflora incarnata

\begin{tabular}{ll} 
Total phytochemicals & Leaf extract \\
\hline Total phenolic content & 2.48 \\
\hline Total tannins content & 1.9 \\
\hline Total alkaloid content & 0.031 \\
\hline Total flavonoid content & 2.1 \\
\hline
\end{tabular}

the average of triplicate and represented as mean \pm standard deviation.

\section{DISCUSSION}

Uptrended studies have suggested the prevalence with increased levels of plant-derived compounds with low optional remedy rates of many diseases. These results suggest a connection between the protecting role of plant compounds in

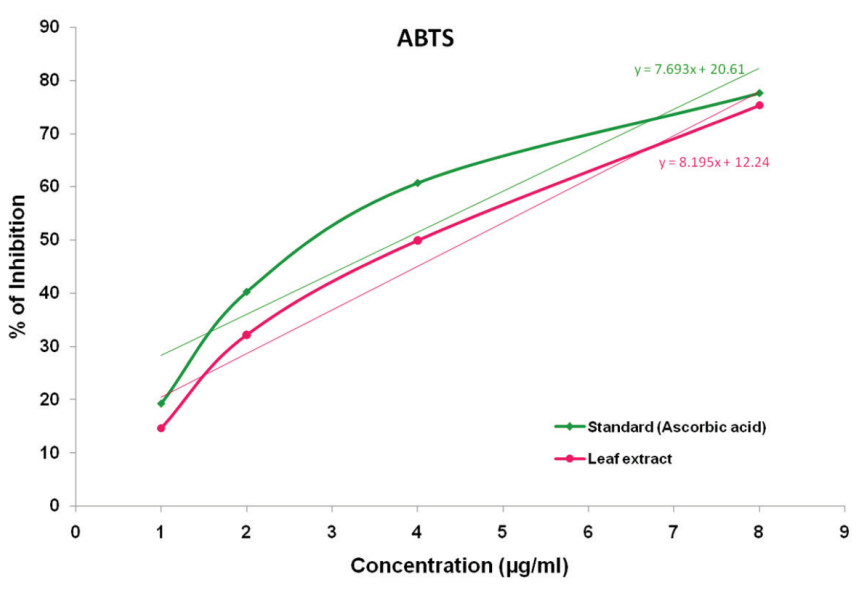

Figure 3. ABTS radical scavenging activity

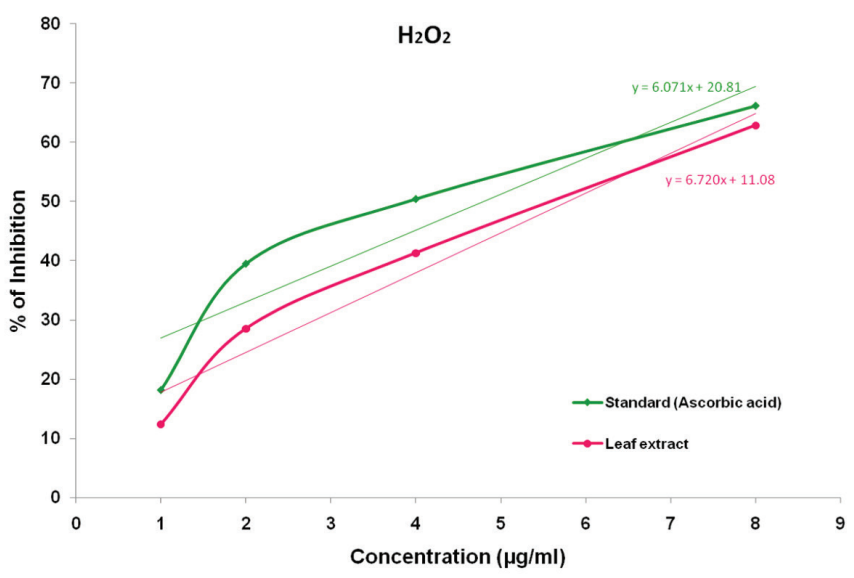

Figure 4. $\mathrm{H}_{2} \mathrm{O}_{2}$ scavenging activity

\begin{tabular}{|c|c|c|c|}
\hline Group & $\begin{array}{l}\text { Concentration } \\
(\mu \mathrm{g} / \mathrm{mL})\end{array}$ & $\begin{array}{l}\% \text { of } \\
\text { inhibition }\end{array}$ & $\mathrm{IC}_{50}$ value \\
\hline \multirow{4}{*}{$\begin{array}{l}\text { Ethanol extract of } \\
\text { leaves of Passiflora } \\
\text { incarnata }\end{array}$} & 1 & $17.43 \pm 0.31$ & \multirow{4}{*}{$4.30 \mu \mathrm{g} / \mathrm{mL}$} \\
\hline & 2 & $30.12 \pm 0.29$ & \\
\hline & 4 & $51.69 \pm 0.43$ & \\
\hline & 8 & $80.91 \pm 0.37$ & \\
\hline \multirow{4}{*}{ Ascorbic acid } & 1 & $22.13 \pm 0.28$ & \multirow{4}{*}{$3.69 \mu \mathrm{g} / \mathrm{mL}$} \\
\hline & 2 & $39.87 \pm 0.33$ & \\
\hline & 4 & $57.28 \pm 0.25$ & \\
\hline & 8 & $82.55 \pm 0.41$ & \\
\hline
\end{tabular}


increasing the average life span of human health. Plant derived compounds have an enormous range of polyphenols, which play a prime role in minimizing the balance between free radicals and antioxidant potential. Substantially, it is needed to optimize these flavonoids to be acknowledged for their efficient action. ${ }^{21}$

Accumulated evidence has suggested that the ethanolic extracts of $P$. incarnata showed a prominent and potent in vitro antioxidant activity with high flavonoid contents (2.1 $\mu \mathrm{g} / \mathrm{mL}$ ). Flavonoids - a phenolic substance, labeled for its phytoconstituents of $P$. incarnata ${ }^{22}$ that can steadily repair the unpaired electrons located in its aromatic ring and can minimize the cause of free radical development. There are scientific reports showing that the number of phenolic compounds is directly proportional to antioxidant activity. ${ }^{23}$ In vitro study has also evidenced a potential activity in aqueous and ethanolic extracts of $P$. incarnata. ${ }^{24} \mathrm{~A}$ group of scientists from Italy studied the methanol extracts from five species of Passiflora obtained by zygotic embryo culture showed DPPH and ABTS radical scavenging activity. ${ }^{25}$ Among the flavonoid constituents, in $P$. incarnata, vicenin, isovitexin, and orentin have major roles in the in vitro antiradical scavenging activity. ${ }^{26}$ A number of flavonoid glycosides - isochaftoside, schaftoside, isoorientin, orientin, vitexin, and isovitexin are considered standard markers to identify different Passiflora

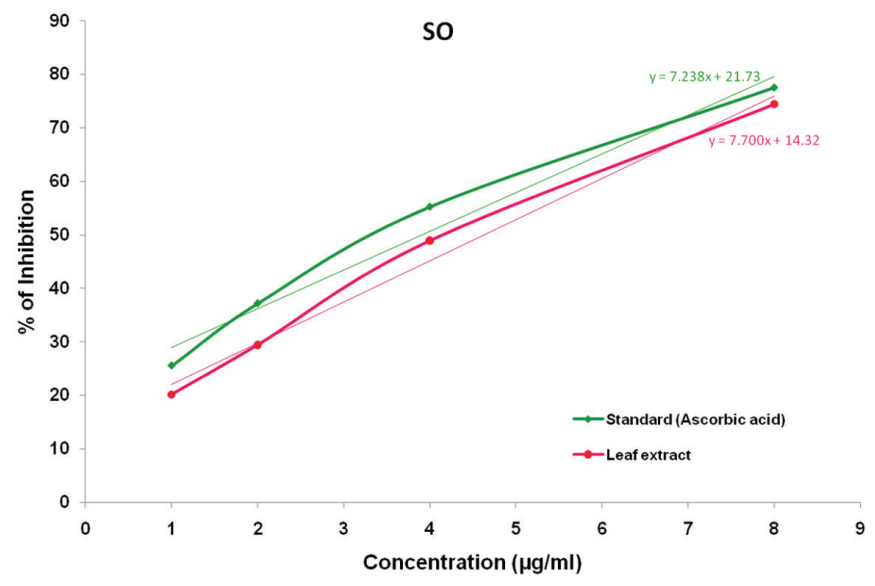

Figure 5. Superoxide scavenging activity

\section{Table 5. ABTS}

\begin{tabular}{|c|c|c|c|}
\hline Group & $\begin{array}{l}\text { Concentration } \\
(\mu \mathrm{g} / \mathrm{mL})\end{array}$ & $\%$ of inhibition & $\mathrm{IC}_{50}$ value \\
\hline \multirow{4}{*}{$\begin{array}{l}\text { Ethanol extract } \\
\text { of leaves of } \\
\text { Passiflora } \\
\text { incarnata }\end{array}$} & 1 & $14.65 \pm 0.17$ & \multirow{4}{*}{$4.60 \mu \mathrm{g} / \mathrm{mL}$} \\
\hline & 2 & $32.16 \pm 0.24$ & \\
\hline & 4 & $49.87 \pm 0.30$ & \\
\hline & 8 & $75.23 \pm 0.33$ & \\
\hline \multirow{4}{*}{ Ascorbic acid } & 1 & $19.32 \pm 0.21$ & \multirow{4}{*}{$3.82 \mu \mathrm{g} / \mathrm{mL}$} \\
\hline & 2 & $40.28 \pm 0.27$ & \\
\hline & 4 & $60.71 \pm 0.31$ & \\
\hline & 8 & $77.56 \pm 0.29$ & \\
\hline
\end{tabular}

species, ${ }^{27}$ such as $P$. edulis, $P$. incanata, $P$. tripartita. Isoorientin, major flavonoid credentials contributing in poly(2-methoxyethyl acrylate) fractions can be the most accountable for the antioxidant activity. Moreover, in vivo approaches, Wistar rats were gavaged with vitexin and isovitexin, noticing the increasing antioxidant capacity. ${ }^{28}$ Most pharmacological studies have demonstrated effects on central nervous system, e.g. anxiolytic, sedative action, and anticonvulsant properties. About 294 volatile compounds have been identified in several passion fruit extracts. ${ }^{29}$ From the results of this study, it is concluded that the ethanol extract of $P$. incarnata with its remarkable phytochemical profile can ensure the promising antioxidant potential.

\section{CONCLUSION}

In green chemistry, the influence of basic phytochemical extraction methods was studied in the $P$. incarnata leaves in order to screen or to obtain its high phenolic compounds. This study investigated the leave extract act as an antioxidant agent in in vitro studies. The results revealed that the flavonoid contents present in $P$. incarnata $(2.1 \mu \mathrm{g} / \mathrm{mL})$ can be an optional to decrease or eradicate the ROS in active levels. Recently, the use of therapeutic ethnomedicinal products has been reliable with adverse effects. $P$. incarnata is a nutraceutical enriched with bioactive compounds, which are evident to possess it as

\begin{tabular}{|c|c|c|c|}
\hline Group & $\begin{array}{l}\text { Concentration } \\
(\mu \mathrm{g} / \mathrm{mL})\end{array}$ & $\%$ of inhibition & $\mathrm{IC}_{50}$ value \\
\hline \multirow{4}{*}{$\begin{array}{l}\text { Ethanol extract } \\
\text { of leaves of } \\
\text { Passiflora } \\
\text { incarnata }\end{array}$} & 1 & $12.43 \pm 0.87$ & \multirow{4}{*}{$5.79 \mu \mathrm{g} / \mathrm{mL}$} \\
\hline & 2 & $28.57 \pm 0.67$ & \\
\hline & 4 & $41.32 \pm 0.72$ & \\
\hline & 8 & $62.84 \pm 0.60$ & \\
\hline \multirow{4}{*}{ Ascorbic acid } & 1 & $18.21 \pm 0.52$ & \multirow{4}{*}{$4.80 \mu \mathrm{g} / \mathrm{mL}$} \\
\hline & 2 & $39.52 \pm 0.41$ & \\
\hline & 4 & $50.43 \pm 0.39$ & \\
\hline & 8 & $66.16 \pm 0.47$ & \\
\hline
\end{tabular}

Table 7. SO

\begin{tabular}{|c|c|c|c|}
\hline Group & $\begin{array}{l}\text { Concentration } \\
(\mu \mathrm{g} / \mathrm{mL})\end{array}$ & $\%$ of inhibition & $\mathrm{IC}_{50}$ value \\
\hline \multirow{4}{*}{$\begin{array}{l}\text { Ethanol extract } \\
\text { of leaves of } \\
\text { Passiflora } \\
\text { incarnata }\end{array}$} & 1 & $20.15 \pm 0.45$ & \multirow{4}{*}{$4.63 \mu \mathrm{g} / \mathrm{mL}$} \\
\hline & 2 & $29.42 \pm 0.38$ & \\
\hline & 4 & $48.88 \pm 0.35$ & \\
\hline & 8 & $74.37 \pm 0.51$ & \\
\hline \multirow{4}{*}{ Ascorbic acid } & 1 & $25.53 \pm 0.29$ & \multirow{4}{*}{$3.90 \mu \mathrm{g} / \mathrm{mL}$} \\
\hline & 2 & $37.19 \pm 0.33$ & \\
\hline & 4 & $55.26 \pm 0.34$ & \\
\hline & 8 & $77.55 \pm 0.39$ & \\
\hline
\end{tabular}


folk medicine for many years and possibly subsidizes to the prevention and cure of many disorders. Further investigations are required to determine the potential use of $P$. incarnata leaves in the pharmaceutical fields could be considered.

\section{ACKNOWLEDGMENTS}

The authors thankfully acknowledge the help of Dr. M. Jegadeesan, Professor and Head, Department of Environmental and Herbal Sciences, Tamil University, Thanjavur for plant identification and authentication.

\section{Ethics}

Ethics Committee Approval: Not applicable.

Informed Consent: Not applicable.

\section{Authorship Contributions}

Concept: S.P., W.E.G., Design: N.B.M., Data Collection or Processing: H.S.R.M., W.E.G., Analysis or Interpretation: S.P., N.B.M., Literature Search: H.S.R.M., N.B.M., Writing: H.S.R.M., N.B.M.

Conflict of Interest: No conflict of interest was declared by the authors.

Financial Disclosure: The authors declared that this study received no financial support.

\section{REFERENCES}

1. Stadtman ER. Role of oxidant species in aging. Curr Med Chem. 2004;11:1105-1112.

2. Marnett LJ. Lipid peroxidation-DNA damage by malondialdehyde. Mutat Res. 1999;424:83-95.

3. Rakesh SU, Patil PR, Mane SR. Use of natural antioxidants to scavenge free radicals: a major cause of diseases. Int J Pharm Tech. Res. 2010;2:1074-1081.

4. Kapadiya DB, Dabhi BK, Aparnathi KD. Spices and herbs as a source of natural antioxidants for food. Int J Curr Microbiol Appl Sci. 2016;5:280-288.

5. Adedapo A, Jimoh F, Afolyana A, Masika P. Antioxidant properties of the methanol extracts of the leaves and stems of Celtis africana. Rec Nat Prod. 2009;1:23-31.

6. Tachakittirungrod S, Okonogi S, Chowwanapoonpohn S. Study on antioxidant activity of certain plants in Thailand: mechanism of antioxidant action of guava leaves extract. J Food Chem. 2007;103:381-388.

7. Zengin G, Aktumsek A, Guler GO, Cakmak YS, Yildiztugay E. Antioxidant properties of methanolic extract and fatty acid composition of Centaurea urvillei DC. subsp. hayekiana Wagenitz. Rec Natural Product. 2011;5:123-132.

8. Li HY, Hao ZB, Wang XL, Huang L, Li JP. Antioxidant activities of extracts and fractions from Lysimachia foenum-graecum Hance. Bioresour Technol. 2009;100:970-974.

9. Radovanović B, Mladenović J, Radovanović A, Pavlović R, Nikolić V. Phenolic composition, antioxidant, antimicrobial and cytotoxic activates of Allium porrum L. (Serbia) extracts. J Food Nutr Res. 2015;3:564-569.

10. Wohlmuth H, Penman KG, Pearson T, Lehmann RP. Pharmacognosy and chemotypes of passionflower (Passiflora incarnata L.). Biol Pharm Bull. 2010;33:1015-1018

11. Zeraik ML, Pereira CAM, Zuin VG, Yariwake JH. Passion fruit: a functional food? Rev Bras Farmacogn. 2010;20:459-471.
12. Harborne JB, Introduction to Ecological Biochemistry. $3^{\text {rd }}$ ed. Academic Press, London. 1967: p. 10-15.

13. Evans WC. Trease and Evans Pharmacognosy. W.B. Saunders Publication, Edinburgh, USA. 1996. p. 36-50.

14. Anonymous. Regional research laboratory (CSIR), Jammu Tawi and Indian Drug Manufacturer's association, Mumbai. 2002. p. 206-213.

15. Asami DK, Hong YJ, Barrett DM, Mitchell AE. Comparison of the total phenolic and ascorbic acid content of freeze-dried and air-dried marionberry, strawberry, and corn grown using conventional, organic, and sustainable agricultural practices. J Agric Food Chem. 2003;51:12371241.

16. Anonymous. Official methods of Analysis, $13^{\text {th }}$ edition. Association of Official Agricultural Chemists, Washington, DC. 2004. p. 47-68.

17. Molyneux $P$. The use of the stable free radical diphenylpicrylhydrazyl (DPPH) for estimating antioxidant activity. Songklanakarin J Sci Technol. 2004;26:211-221.

18. Re R, Pellegrini N, Proteggente A, Pannala A, Yang M, Rice-Evans C. Antioxidant activity applying an improved ABTS radical cation decolorization assay. Free Radic Biol Med. 1999;26:1231-1237.

19. Ruch RJ, Cheng SJ, Klaunig JE. Prevention of cytotoxicity and inhibition of intercellular communication by antioxidant catechins isolated from Chinese green tea. Carcinogenesis. 1989;10:1003-1008.

20. Liu F, Ooi VE, Chang ST. Free radical scavenging activities of mushroom polysaccharide extracts. Life Sci. 1997;60:763-771.

21. Bungau S, Abdel-Daim MM, Tit DM, Ghanem E, Sato S, MaruyamaInoue M, Yamane S, Kadonosono K. Health benefits of polyphenols and carotenoids in age-related eye diseases. Oxid Med Cell Longev. 2019;97:429.

22. Raffaelli A, Moneti G, Toja E. Mass spectrometric characterization of flavonoids in extracts from Passiflora incarnata. J Chromatogr. 1997;777:223-231.

23. Zhou YC, Zheng RL. Phenolic compounds and an analog as superoxide anion scavengers and antioxidants. Biochem Pharmacol. 1991;42:11771179.

24. Dhawan K, Kumar R, Kumar S, Sharma A. Correct identification of Passiflora incarnata Linn., a promising herbal anxiolytic and sedative. J Med Food. 2001:4:137-144.

25. Bendini A, Cerretani L, Pizzolante L, Toschi TG, Guzzo F, Ceoldo S, Marconi AM, Andreetta F, Levi M. Phenol content related to antioxidant and antimicrobial activities of Passiflora spp. extracts. Eur Food Res Technol. 2006;223:102-109.

26. Masteikova R, Bernatoniene J, Bernatoniene R, Velziene S. Antiradical activities of the extract of Passiflora incarnata. Acta Pol Pharm. 2008;65:577-583.

27. Sakalem ME, Negri G, Tabach R. Chemical composition of hydroethanolic extracts from five species of the Passiflora genus. Braz J Pharmacogn. 2012;22:1219-1232.

28. Cao D, Li H, Yi J, Zhang J, Che H, Cao J, Yang L, Zhu C, Jiang W. Antioxidant properties of the mung bean flavonoids on alleviating heat stress. PLoS One. 2011;6:e21071.

29. Esquivel P, Stintzing FC, Carle R. Phenolic compound profiles and their corresponding antioxidant capacity of purple pitaya (Hylocereus sp.) genotypes. Z Naturforsch C J Biosci. 2007;62:636-644. 